\title{
ACHIEVING IMPROVED FINANCING FOR LOW-INCOME PRODUCERS IN DEVELOPING COUNTRIES: THE FIRST SET OF APPROACHES
}

M. G. MAIANGWA

(Received 17 June 2012; Revision Accepted 28 August 2012)

\begin{abstract}
Poor people commonly have limited access to financial services. More specifically, micro entrepreneurs and small-scale business enterprises in developing countries have difficulties in obtaining financial assistance from banks and other financial institutions. Infact, studies have shown that most small enterprises start their lives without any institutional help. The entrepreneur usually obtains the small amount of finance he needs from his own savings or from his family. However, small enterprises find it difficult to grow without the opportunity to borrow from lending institutions. This paper reviews the first set of approaches for achieving improved access to financing for low-income producers in developing countries. For the poor with relatively fewer assets, improved access to finance allows them to manage risk and smooth consumption; finance technological and capital improvements and thereby raise productivity; acquire working capital to obtain inputs in a timely way; and take advantage of market opportunities that contribute to growth.
\end{abstract}

KEY WORDS: Approaches, Improved Access, Finance, Low-Income, Producers.

\section{INTRODUCTION}

Poor rural producers need and use a variety of financial services, including loans, deposits, and other services. They use financial services for the same reasons as anyone else: to smooth consumption over time; cope with emergencies; finance technological and capital improvements and thereby raise productivity; acquire working capital to obtain inputs in a timely way; and to seize business opportunities (Saito et al., 1994; Littlefield and Rosenberg, 2004).

However, many of the poor in Africa still lack access to financial services, with demand for microcredit far outstripping supply (Markowski, 2001). According to some estimates, only 3 percent of families wanting a loan are actually served (Table 1 ). A related report is that some 500 million economically - active poor people around the world have no access to financial services (IFAD, 2000).

TABLE 1. Demand/Supply Gap in microcredit in Sub-Saharan Africa

\begin{tabular}{l|l}
\hline Population (No.) $^{\mathrm{a}}$ & 440 million \\
Poor $^{\mathrm{a}}$ (No.) & 270 million \\
Poor families $^{\mathrm{b}}$ (No,.) & 54 million \\
Family with potential demand $^{\mathrm{c}}$ (No.) & 27 million \\
Average loan per family (US\$) & 200 \\
Theoretical demand for loans $^{\text {(US } \$)}$ & 5,400 million \\
Current microfinance portfolio $^{\mathrm{d}}$ (US\$) & 150 million \\
\hline
\end{tabular}

${ }^{a}$ : Income of US $\$ 2$ a day per person or less

b: Average family size of five

c: Half the poor families can use a microloan

d: Based on inventory of 180 organizations and international agencies.

Source: Markowski, 2001.

Over the last four decades, governments in many developing countries have intervened heavily in rural financial markets. Their intervention has been motivated by the belief that a shortage of affordable credit constrains agricultural growth and prevents the integration of small farmers into the market economy (Huppi and Feder, 1990; Braverman and Huppi, 1991; Besley, 1994). The most frequent forms of intervention 
have been administrative allocation of funds, interest rate ceilings, and the establishment of specialized rural financial institutions (Braverman and Huppi, 1991). Many donors have actively supported these interventions.

The performance of most credit programmes has, however, fallen short of expectations. Some of the factors implicated in the limited success of subsidized credit programmes include: (i) the politicization of parastatal agricultural credit institutions (since they are owned by governments) which led, in turn, to funds from these institutions, being skewed in favour of wealthier and more influential farmers, without strict observance of effective lending criteria; (ii) political constraints to loan recovery and political pressure to maintain low and financially unjustifiable interest rates; and (iii) undue reliance on external sources of subsidized funds which facilitated these abuses and made nearly all of the credit schemes unsustainable. The result was poorly performing portfolios, low loan recovery, and heavy financial losses (Adams et al., 1984; Von Pischke and Rouse, 1983; Cleaver, 1993).

The failure of agricultural development banks and other rural lenders to reach low-income producers with affordable credit has led to a search for other arrangements. This paper discusses the first set of approaches by which improved financing for such lowincome producers can be better achieved.

\section{First Set of Approaches for Achievement of} Improved Financing for Low-Income Producers

Use of lending groups and credit cooperatives. Both entities have the potential to reach small farmers with affordable credit because processing one large loan rather than numerous small loans cuts administrative costs. Besides, since credit cooperatives and group lending arrangements entail some form of joint liability, they are also expected to reduce the risk of default (Huppi and Feder, 1990). Familiarity among group members or between the cooperative management and its members also allows the reduction of informational costs linked to the reduction of adverse selection and moral hazard behaviour (Braverman and Huppi, 1991). Thus, by reducing the costs to both lender and borrower of information related to screening and strengthening repayment incentives and contract enforcement, these arrangements can help to expand credit services to clients (Stiglitz, 1990). For these reasons, it is frequently argued that agricultural development banks and commercial banks could continue to serve mediumsized and large farmers directly, while serving small farmers indirectly through lending groups or credit cooperatives. The Grameen Bank (GB) in Bangladesh and the Bank for Agriculture and Agricultural Cooperatives (BAAC) in Thailand have leaned heavily on self-help groups to promote and deliver loans, thus generating substantial savings in their transaction costs. According to Yaron (1994), the smallness of the group (five members in the GB and up to thirty in the BAAC) has eliminated or drastically reduced the emergence of free riders. He further pointed out that each individual's performance is crucial in determining the group's success or failure, thereby creating a sense of affiliation that has resulted in efficient, successful financial intermediation.

Liberalization of interest rates: Liberalized interest rates can be expected to decrease overall demand for credit, so that small producers' access to funds should to a certain extent be improved (Braverman and Huppi, 1991). Other advantages of the liberalization of interest rates are that: (i) it decreases the incentives for patronage and arbitrary decisions, and thus helps improve the regressive character of subsidized credit programmes; and (ii) it allows rural financial intermediaries to cover their operational costs and to effectively mobilize rural savings. This would make them more independent from external financial sources, while making them responsible for managing their own funds (Braverman and Huppi, 1991; Holt and Ribe, 1991). Experience has shown that the price of loans is a relatively unimportant factor in inducing farmers to borrow. Much more important are timely services and simple application and disbursement procedures (Braverman and Huppi, 1991). The rationale for providing credit at below-market rates is further undermined by evidence that the poor are willing to pay market rates. For example, a study of rural financial markets in Bangladesh, which experimented with lending at annual interest rates ranging from 12 percent to 36 percent, found that small producers' demand for loans remained relatively inelastic up to an interest rate of about 30 percent (USAID, 1983). Moreover, poor people borrow routinely from informal credit markets where interest rates have historically exceeded formal market rates. Also, since lending to poor producers involves high risk, the risk premium must therefore be high. When credit is subsidized, borrowers tend to regard it as charity and make little effort to repay (Hung, 2004). The four rural financial institutions widely perceived to be successful, namely: the Badan Kredit Kecamatan (BKK) and the Bank Rakyat Indonesia Unit Desa (BUD) in Indonesia, the Bank for Agriculture and Agricultural Cooperatives (BAAC) in Thailand, and the Grameen Bank (GB) in Bangladesh, have charged positive real interest rates on their loans, with nominal rates ranging from 11 to 130 percent a year (the upper bound has been charged only on a very small share of BKK short-term loans). For BUD and BKK, real rates have been greater than 15 percent annually, and for BAAC (which has specialized in "mass production" of uniform short-term loans to self-help groups) and the $\mathrm{GB}$, real rates have been below 10 percent per annum. These data supported the notion that access to credit, rather than the subsidy embodied in negative interest rates, has been the important factor for the ultimate borrowers (Yaron, 1994; Yaron, 1995). Despite the positive and frequently high on-lending rates used, the rates were significantly below the interest rates prevailing in the informal money markers. Legally imposed ceilings on lending interest rates have existed in the cases of BAAC and GB, but the other two RFIs (BUD and BKK) have been free to adjust lending rates 


\section{THE FIRST SET OF APPROACHES}

to reflect the financial and administrative costs involved. All four RFIs have also provided savings services, with varying degrees of success when the amounts were measured against the value of their loan portfolios.

Deposit rates have been positive for BUD and BAAC, with the average value of deposits significantly higher than those of BKK and GB. The interest rates applied by BKK and GB to obligatory savings, also known as "compensating balances" (that is, the borrower must set aside part of the loan in a fixed term deposit) have been lower than the lending rates, implying higher effective lending interest rates and a smaller effective loan size (Yaron, 1994; Yaron, 1995).

Mobile Banking: The so-called bank-on-wheels is a creative way not only for lenders to reach out to the poor, but also for the poor to "reach in" to lenders, thereby reducing the poor's transaction costs and improving their economic prospects (Hung, 2004). For example, the Vietnam Bank for Agriculture and Rural Development (Agribank), with one of the most extensive branch networks in the world, initiated in 1998 a mobile banking programme, modelled after similar programmes in Bangladesh and Malaysia. It procured 150 vehicles equipped to travel on dirt roads and hilly pathways, enabling loan officers to reach remote areas to process loan applications, disburse money, collect repayments, and mobilize savings deposits. The visits followed a fixed calendar and were announced in advance. Scheduled to coincide with weekly village markets, they saved borrowers travelling time and transportation costs. Once the programme was launched, it became clear that more than just difficult access prevented the poorest from taking advantage of its services. Their isolation caused them to have feelings of helplessness and fear. In the upland ethnic group, the higher up a mountain people lived and the longer their isolation, the more they seemed to believe that they could not get credit. Above all, the poorest people lacked confidence and selfesteem. For example, the illiterate poor would wonder how they could fill out applications and receipts. Others felt they could do nothing to earn extra income to repay a loan. Thus, many were afraid to venture into activities other than cultivation and animal husbandry, even though opportunities existed. An assessment of Vietnam's mobile banking programme five years after its introduction showed that it was relatively cost effective and provided financial services to 315,000 poor households, about 6 percent of Agribank's clients. Preliminary data showed that, on average, each mobile bank disbursed 1,921 loans, collected 1,387 payments, and transported cash on 75 occasions to 16 local points monthly. The excellent repayment rate suggested that the poor are good credit risks. The programme also mobilized 1,983 small savings accounts monthly, thereby showing that the poor can be good savers (Hung, 2004). For mobile banking to work for borrowers, however, some services have to be made available. These include: (i) offering appropriate loan products to meet the needs and circumstances of the poor. For Agribank, it involved diversifying its loan portfolio and considering a range of low-cost products that would be easy to understand and use and could be disbursed when they are needed; (ii) linking lending and saving; for Agribank, linking the two meant that when credit officers disbursed loans and collected payments, they were also responsible for mobilizing savings. The bank made savings voluntary rather than mandatory and offered people incentives to open savings accounts. These included guaranteed safety for deposits and attractive interest rates for different maturities; and (iii) combining credit and human asset building. When credit is combined with training, borrowers become more productive and are more likely to repay their loans. Lenders and non-governmental organizations can work with local agencies to provide information about the market and profitable opportunities and to explain market risk and how to cope with it (Hung, 2004).

Supervised Credit and Hiring: Supervised credit is credit which is offered in conjunction with technical advice and assistance (Upton, 1973). The credit agent, who must be a trained agricultural extension worker, first helps the farmer to make a productive plan for his farm for the coming year. It includes an estimate of the amount of credit needed to finance the plan and the probable value of the increased product. Credit is then provided either in cash or in the form of the specific supplies and equipment needed. The credit agent visits the farmer from time to time, giving technical advice and checking that the farmer is following the plan drawn up. In some cases, new inputs such as new seeds, fertilizers, or machinery services are offered. Thus, the credit and the technical assistance are complementary to each other. The credit ensures that the farmer can finance the new techniques and these in turn ensure sufficient increase in income to repay the loans with interest, while the close supervision ensures that credit is used productively (Upton, 1973). Also, where credit agencies work closely with the agricultural extension service, it has proven beneficial as it helps the former make use of the latter's knowledge of individual farmers. This helps to minimize asymmetrical information (when lenders know little about borrowers). Hiring is also a form of credit particularly applicable to machinery and possibly livestock. Where a machinery hire service is intended to be self-supporting, the charges must cover the costs not only of repairs, maintenance, depreciation and operator wages but also interest on the capital invested (Upton, 1973). Livestock hiring schemes exist in some parts of Africa often with interest payments being paid in kind. For instance, in Southeastern Ghana, Fulani herdsmen tend cattle owned by members of the local Ewe tribe. The calves which are returned to the owners may be viewed as a hire charge (Upton, 1973).

Developing Client Skills and Institutions: Numerous expert reports and meeting documents have proven that agricultural credit expansion is hampered by farmers' lack of knowledge about the availability and conditions of credit, and by the shortage of well-trained bank staff, who have experience in dealing with small farmers and rural people (Laure, 1973; Roberts, 1980). Training, therefore, should focus both on farmer clients and bank staff. Poor people who have never used a bank account 
or filled out application forms must be taught how to do so. Learning about institutional credit increases clients' confidence in themselves and in the financial institution. According to Holt and Ribe (1991), training and confidence-building are particularly important for women, who are likely to have less formal education and familiarity with formal procedures. This investment increases initial transaction costs for both the financial intermediary and its clients but is absolutely essential (Von Pischke, 1989). At the Association for the Development of Microenterprises (ADEMI) in the Dominican Republic, advisors escort new clients to the bank and take them step by step through chequecashing and depositing procedures (Reichmann, 1989). At the Savings Development Movement in Zimbabwe, households are organized into neighbouring groups and are taught a financial record-keeping system illiterate people can use (Bratton, 1990). The Grameen Bank in Bangladesh devotes painstaking attention to building its clients' confidence and skills. Group members need confidence because they are often nervous about taking a loan and striking out on their own in activities funded by that loan (Von Pischke, 1989). After they form, groups receive seven days of instruction from Grameen Bank workers. Financial institutions, on the other hand, also need training and assistance. Some studies (Huppi and Feder, 1989; Braverman and Guasch, 1989; Mann et al., 1989; Holt, 1990) have indicated that financial services programmes require well-functioning institutions and qualified staff to maintain performance and ensure sustainability. Banks' field staff should have appropriate education and training in business and farm management, agriculture, and banking (Roberts, 1980). In their work, they should interact closely with agricultural extension agents and organizations, who provide essential non-financial support services to small farmers and rural people. Such liaison should involve sensitizing farmers about the availability and conditions of bank credit and assist farmers in preparing proper farm and business plans and submitting loan applications. Extension agents and similar technical staff, however, should not be involved in loan approval and loan recovery, which remains the exclusive task of banks (FAO/GTZ, 1998). Banks should accept staff training as an investment, forming part of overall manpower development. This needs to be reflected when recruiting staff, bearing in mind that poor recruitment practices may result in poor recruits which cannot be easily rectified by training (FAO/GTZ, 1998). Boomgard (1989) cites a stocktaking study by the United States Agency for International Development (USAID) to have found that successful lending institutions shared the following characteristics:

- A clear, unambiguous objective that is well understood and accepted at all levels of the organization.

- Strong and charismatic leadership by an individual with strong links to local elites.

- A well-trained staff whose dedication is cultivated through training, equitable personnel plans and financial incentives.
- Tight management information systems and forms of financial control, often computerized; and

- Flexibility, especially the ability to learn from experience and adapt to changing circumstances.

Financial assistance from governments and donors can also be important to client training and institution building (Holt and Ribe, 1991).

Targeted and untargeted lending: Targeting credit to poor clients has the advantages of: (i) facilitating access to credit by groups traditionally ignored by the formal financial sector such as smallholders, women and microenterprises in rural areas, and (ii) helping to overcome obstacles such as poor information, lack of lender experience and expertise in lending to these groups and absence of lender confidence in the borrowers (Cleaver, 1993). Thus, targeted credit helps where the formal financial sector is shallow. Organizations like the Self-Employed Women's Association (SEWA) in India, the Badan Kredit Kecamatan in Indonesia, and the Grameen Bank in Bangladesh target with considerable success. For example, a random survey of Grameen Bank borrowers revealed that more than 95 percent of its participants came from households that owned less than 0.5 hectares of cultivable land (Holt and Ribe, 1991). Targeting poor clients effectively, however, requires: (i) familiarity with their needs, which requires market research, and (ii) being able to develop a product or service that meets local needs (Holt and Ribe, 1991). By understanding a new product or service's potential users and their needs, innovative financial institutions can decrease the risk of innovation (Von Pischke, 1989). Targeting key sectors such as agriculture in the context of a reforming financial sector using private banks and cooperative institutions and in some cases banks involving government participation at unsubsidized interest rates, is necessary to stimulate commercial agriculture in Africa (Cleaver, 1993). Other experts have, however, argued that one of the major weaknesses of the directed agricultural credit approach to finance was that it tried to target low-income clients with lending targets, quotas and subsidized interest rates, in addition to emphasizing lending to priority sectors (usually agriculture and small farmers), as opposed to lending to other kinds of rural incomegenerating activities. Such preferential credit programmes tended to curtail rather than expand their outreach to small farmers and other customers in rural areas, thus limiting their potential to serve a wider clientele (Seibel, 2000). Supporters of the market performance approach to finance have, therefore, emphasized open, untargeted lending, as against targeted lending emphasized by the directed credit approach.

Reduction of Transaction Costs and Provision of Transaction Cost Subsidies: A prerequisite for increasing poor rural producers' access to financial services is to reduce transaction costs for both lenders and borrowers (Holt and Ribe, 1991). Studies have 
indicated that total non-interest borrowing costs, especially for small borrowers sometimes greatly exceed nominal interest payments (Adams and Nehman, 1979; Adams and Graham, 1984; Christen, 1989). Borrowers' costs may also increase when formal loans are not disbursed quickly. Also because of women's multiple work obligations in the household and market place, they incur high opportunity costs for foregone labour (Berger, 1989; Hossain and Afsar, 1989). Poor women on average work longer hours than men of the same class when both household and market tasks are counted, hence women who want access to credit can be easily discouraged by high transaction costs (King and Evenson, 1983). Reducing transaction costs for borrowers will mean finding non-traditional methods of overcoming collateral requirements and decreasing the costs of intermediation with financial institutions through such strategies as group lending (as discussed earlier). For lenders, reduction of transaction costs will mean decreasing lenders' risks and administrative costs, also partly through group lending. Some lending programmes have also succeeded in reducing loan risks by starting with small disbursements and increasing them in subsequent loans as borrowers establish strong repayment record (Holt and Ribe, 1991). Like many programmes, the Badan Kredit Kecamatan (BKK) programme in Indonesia complements this approach with other measures to reduce lender and borrower transaction costs. To decrease processing expenses and replace collateral requirements, tiny loans are made by BKK on the basis of character references from local officials, one-page application forms are processed in less than one week, and loans are not supervised (Holt and Ribe, 1991). In situations in which the constraint is not capital scarcity, but rather the high cost of lending to farmers, some experts have argued for transaction cost subsidies for lenders, as a lump sum per loan made. According to these experts, several projects along this line are under preparation in Guinea, Uganda, Cameroon and Madagascar (Cleaver, 1993).

\section{Concept of agricultural warrantage (locked-in loans} or inventory credit): Under warrantage, farmers can leverage their produce inventories for credit. Instead of selling their produce immediately after harvest (when prices are lowest) to generate financing for the following season, farmers can store their harvest and use it as collateral for bank credit. The produce is stored in locked warehouses secured by banks, which then extend credit based on the value of the stored harvest (IMF, 2010). Farmers can use the up-front bank finance to purchase inputs for the next season, while also storing their harvest until deep into the off-season when produce scarcity boosts prices. When the stored produce is marketed at off-season prices, farmers can use the proceeds to pay off the banks and retain any remaining earnings as profit (IMF, 2010). In Ghana, TechnoServe, a U.S.-based NGO has applied the use of inventory credit for grain marketing, particularly maize and rice (Markowski, 2001). The price of maize during the lean season is typically 75 to 250 percent higher than the price at harvest time. The amount of credit provided by local banks is pegged to a proportion of the current market value of the stored grain, usually between 70 and 80 percent of the prevailing market price. This limits the lender's risk should the price not rise as anticipated. On average, in a period of 5 years, farmers participating in the programme have increased their net income by 36 percent over what they would have earned had they sold their maize immediately after the harvest. More significantly, the scheme has achieved a 100 percent repayment rate (Markowski, 2001). The importance of the concept of agricultural warrantage is underscored by the fact that the Food and Agriculture Organization (FAO) plans to extend the concept to Burkina Faso, Mali, and Senegal after a test project boosted farm incomes and crop yields in Niger.

Credit-with-Education: This is another financial product that has proven to be very much in demand. This product has been promoted by Freedom-fromHunger, another U.S.-based NGO (Markowski, 2001). Field officers travel on motorbikes to remote villages in rural areas where they set up and coach groups of 30 women through regular weekly meetings. Group members go through various cycles of loans, which must be repaid over a period of 4 months. Initial loan amounts of US $\$ 50$ are gradually increased up to US $\$$ 250 (Markowski, 2001). The originality of Credit-withEducation resides in the fact that, as the name indicates, field officers use group meetings to educate members not only on managing their income-generating activities but also on reproductive health, child nutrition, and other matters of importance for their well-being. Creditwith-Education is successfully used as a leading financial product by more than 60 percent credit unions in Mali and Burkina Faso, as well as a number of rural banks in Ghana. In Burkina Faso, where Credit-withEducation is known as caisses villageoises, 30,000 women participate (Markowski, 2001).

Multi-purpose financial institutions: Given the diversity of income sources upon which the poor depend and their need for both production and consumption credit as well as savings outlets, it is apparent that multipurpose financial institutions would be more useful to the poor than specialized savings and lending institutions (Braun, 1992). Institutions that offer only highly restrictive lines of credit and prohibit consumption loans are not likely to be perceived as helpful establishments for retaining household savings in anticipation of rural loans (Meyer and Gonzalez-Vega, 1986). For example, in Sierra Leone, approximately 70 percent of farmers' demand for credit relates to subsistence and consumption needs. These are not met by institutional credit systems, which typically provide only production loans for a specific purpose (Johnny, 1985). Under the directed credit approach, loans were meant for agricultural production and because farming is a seasonal occupation, agricultural lending institutions experienced the boom and bust of cash flows, with loan requirements drastically increasing during the sowing season. In addition, an emphasis on providing loans strictly for agricultural activities as 
opposed to providing credit for other kinds of rural income-generating activities limited the potential of agricultural development banks to serve a wider clientele (Seibel, 2000). Some experts have argued that limiting loans to productive purposes sometimes leads to situations which are difficult to defend. For example, Stickley (1976) argues that the institutionalized agricultural lenders of Tunisia approved loans for production but not consumption. The productive loan purpose, according to him, was so narrowly defined that it excluded some of the loan purposes that were most important to small farmers. Whereas feed, shelter and veterinary services for work animals were considered legitimate productive loan purposes, food, clothing, shelter and healthcare for the farm labourer and his family were not considered as productive loan purposes. For the small farmer who typically operates a labourintensive system of farming, labour maintenance represents one of his major farm expenses.

Loan processing: Transaction costs incurred by the borrower are a frequently mentioned aspect differentiating between institutional and non-institutional sources of credit. In many areas, the procedures required to obtain institutional loans are time-consuming, both in terms of actual time spent by the farmers (obtaining appropriate documentation, filling forms, meeting relevant officials) and the time which elapses between loan application and credit approval (Feder et al., 1986). According to Yaron (1994), two problems in particular confront rural financial institutions: first, ensuring efficient and relatively low-cost operational procedures for screening borrowers, processing and monitoring loans, and mobilizing and servicing voluntary savings, and second, achieving adequate loan collection so that continued operations are feasible without constant reliance on state concessional funds or bailouts. Borrowing from the four rural financial institutions in developing countries generally considered to be successful --- the BKK, the BUD, the BAAC, and the GB --- does not seem to carry high transaction cost. For example, for the four RFIs, the time between submitting loan application and disbursement has ranged between one and two weeks for first-time borrowers. In the case of $\mathrm{BKK}$, only one day is required for a repeat borrower (facilitated by the one-page application form).

Staff incentive programmes: Managers, supervisors, and loan officers of rural financial institutions must be provided with the incentives to screen loan applications, monitor investment and repayment performance, and enforce loan contracts. All the four successful RFls ----BKK, BUD, BAAC and GB ---- have adopted a diversified reward regime with incentives aimed at motivating staff to perform better in assessing, extending, and collecting loans, and in promoting and servicing savings. BKK distributes 10 percent of a branch's profits to its staff. BUD provides a yearly bonus of up to one month's salary and grants special awards for outstanding performance. BAAC has based its promotion system on three quantifiable factors: loan extension, loan collection, and savings mobilization. GB promotes staff members according to the profits a branch makes, in addition to an annual distribution of 10 percent of a branch's profits to its staff. By tying employee bonuses to quantifiable performance criteria, these incentive programmes have succeeded in increasing accountability and motivating staff (Yaron, 1994; Yaron, 1995). Also, strict accounting and auditing procedures, rewards according to performance (including loan collection) and rotation of key employees can help make a financial institution more efficient, while lowering the possible losses through misallocation and patronage (Braverman and Huppi, 1991).

Management information systems: Accurate and timely information systems are crucial for good operational management. Successful lenders have invested wisely in the acquisition of an adequate banking software to computerize their accounting and management information systems consistent with their specific requirements. The required sophistication of bank automation depends on the volume and the scope of the financial services and on the organizational and operational structure of the financial institution. Ideally, loan portfolio monitoring and reporting on loan disbursements and reimbursements of branch offices should be integrated with liquidity fund management. This ensures that the necessary information is available to the head office in a timely manner (Klein et al., 1999). Computerized and integrated loan accounting and management information systems that produce frequent reports guarantee that loan officers and bank management can respond promptly to potential loan delinquency problems. It is the responsibility of field staff to examine the reasons for overdue loans. Based on their reports, an immediate decision should be taken on corrective follow-up actions. In cases where legitimate reasons for overdue loan repayments exist, loan rescheduling may be allowed (Klein et al., 1999). Deficient accounting practices and inadequate record keeping can therefore make it difficult to determine when payments are overdue and loan agreements must be enforced (Braverman and Huppi, 1991).

\section{CONCLUSION AND RECOMMENDATIONS}

Lack of access to credit is the shortcoming most frequently cited by microentrepreneurs. Infact, government intervention in rural financial markets has been motivated by the belief that a shortage of affordable credit constrained agricultural growth and development and prevented the integration of small farmers into the market economy. Thus, improved access to financial services can help raise the productivity and incomes of microentrepreneurs and small businesses. The key challenge in rural finance, however, remains the emergence of financially and institutionally sustainable MFIs both capable of, and committed to, serving the needs of poor microentrepreneurs. This is expected to lead to a sustained expansion in the range, and improvement in the quality, of key financial services available to poor microentrepreneurs and/or a permanent reduction in the price of such services. This, in turn, will contribute to 
increased incomes among the microentrepreneurs utilizing those services and their employees, and improved household welfare among the families of microentrepreneurs and microenterprise workers. The recommendations for this paper are:

(i) The formation of lending groups and credit cooperatives should be encouraged. These arrangements reduce risks and administrative costs for lenders and, for poor clients, help overcome collateral requirements and decrease the costs of intermediation with financial institutions.

(ii) The participation of the rural poor in the development of rural finance is of crucial importance. This is because the poor will be more willing to pay for services that are tuned to their demands and not to our development priorities. According to Markowski (2001), the shift from credit-led to demand-led services means a much more respectful interaction with the rural poor because we take their concerns and priorities seriously. At the same time, he argued, it means we make them more responsible for their financial obligations.

(iii) Given the adverse effects of subsidized credit programmes, the general continuation of credit subsidies has to be seriously questioned. Liberalization of interest rates for lending to agriculture would allow rural financial intermediaries to cover their operational costs. They could then be required to operate as financial entities which face bona fide profit constraints. Liberalized interest rates also decrease overall demand for credit, so that small farmers' access to funds should, to a certain extent, be improved. However, interest rates must be high enough to ensure the lender's sustainability and low enough to be acceptable to borrowers. Many experts insist that the poor are capable of paying high interest rates and are willing to do so.

(iv) Since policies to direct credit to the poor through subsidies and regulations have largely failed, public funds may be better invested in helping the poor have access to infrastructure such as roads and irrigation, and services such as agricultural extension and market information. Without adequate markets and infrastructure, credit is likely to remain debt, as borrowers have limited options to make profitable investments. According to Holt and Ribe (1991), a viable financial sector that is not undermined by subsidized interest rates and other regulations may be the best way to help the poor make the best use of public investments.

(v) Rather than subsidize finance which would undermine the viability and sustainability of financial institutions and their services, donors and development banks should subsidize the preparation costs of financial systems development, the expansion and differentiation of the financial infrastructure as well as institutionbuilding and capacity enhancement on several system levels. This assistance may cut across the dividing lines between the formal and informal financial sectors.

(vi) An effective alternative to subsidizing the interest rates is to support livelihoods through an asset acquisition matching grants scheme that helps the very poor to build up their income to a level where they will be able to access unsubsidized financial services. According to the World Bank (2008), grant programmes must have three characteristics if they are to achieve their objectives: (i) grants must target the extremely poor who are too vulnerable to take on the risk of a loan or who have assets but cannot absorb downside risk; (ii) grants must have a rigorous targeting strategy and monitoring system, using participatory mechanisms to identify the poorest members of the community; and (iii) grants should be made on a matching basis, either in cash or in kind, requiring the highest contribution that is reasonable for the participant.

(vii) The poor need local financial institutions offering a broad range of financial services which at the same time generate internal resources. Supporting the evolution of different types of financial institutions and strategies is therefore very important. Such institutions must be tailored to the potential of the area, the cultural environment, and the requirements of the clients. As has been rightly stressed by Holt and Ribe (1991) and Von Pischke (1989), investigating prospective clients to assess their needs will help in developing a product and service delivery model suitable for local circumstances.

(viii) Since only sustainable financial institutions can reliably provide adequate financial services and continually increase their outreach to the poor, rural financial institutions must offer attractive interest rates or profit-sharing margins on savings with positive real returns and mobilize their own resources; charge market rates of interest on loans and cover all their costs from the interest rate margin; and must also make a profit and finance their expansion from their returns. According to IFAD (2001), only financial institutions that have demonstrated their capacity for resource mobilization, cost coverage, profitability and dynamic growth deserve assistance.

(ix) Existing rural financial institutions must be restructured in a way that they can eventually function in a competitive environment. They must be encouraged to spread their risks through portfolio diversification and thus lend to rural enterprises other than agriculture.

(x) For lenders that have adopted a "credit-only" approach, provision of training and technical assistance to clients is necessary. In the alternative, these lenders should establish collaboration agreements with partner agencies 
for the provision of non-financial support services. It is important, however, that clients should generally be able to choose which services they need, rather than being offered a fixed package of financial and non-financial services on a take-it-orleave-it basis.

(xi) The provision of access to loans should involve flexible and simple procedures and rules that are easy to understand by the rural population. This means that there has to be total departure from the pervasive red tape associated with supply-led financial institutions which led to high transaction costs for their clients.

\section{REFERENCES}

Adams, D. and D. H. Graham., 1984. "A critique of traditional agricultural credit projects and policies". In Agricultural Development in the Third World, C. Eicher and J.M. Staatz (eds.), Baltimore: Johns Hopkins University Press.

Adams, D. W. and G.I. Nehman., 1979. "Borrowing costs and the demand for rural credit", Journal of Development Studies, 15: 165 - 176.

Adams, D. W., D. H. Graham and J. D. Von Pischke., 1984. Undermining Rural Development with Cheap Credit, Boulder, Colo.: Westview.

Berger, M., 1989. "Giving women credit: The strengths and limitations of credit as a tool for alleviating poverty", World Development, 17(7): 1017-1032.

Besley, T., 1994. "How do market failures justify interventions in rural credit markets?". The World Bank Research Observer, 9: 27 - 47.

Boomgard, J., 1989. AID Microenterprise Stock-Taking: Synthesis Report, AID Evaluation Occasional Paper, United States Agency for International Development, Washington, D.C.

Bratton, M., 1990. "Non-governmental organizations in Africa: Can they influence public policy?". Development and Change, 21: 87-118.

Braun, J. V., 1992. "The development of rural financial markets in sub-Saharan Africa". In Policy Options for Agricultural Development in SubSaharan Africa, N.C. Russell and C.R. Dowswell (eds.), Proceedings of a Workshop, Airlie House, Virginia, August $22-25$.

Braverman, A. and J.L. Guasch., 1989. Rural Credit in Developing Countries, Policy, Planning and Research Working Paper No. 219, The World Bank, Washington, D.C.

Braverman, A. and M. Huppi., 1991. "Improving rural inance in developing countries", Finance and Development, 28(1): $42-44$.
Christen, R. P., 1989. What Microenterprise Credit Programmes Can Learn From Moneylenders, Discussion Paper No. 4, Cambridge, Mass.: ACCION International.

Cleaver, K. M., 1993. A Strategy to Develop Agriculture in Sub-Saharan Africa and a Focus for the World Bank, Technical Paper No. 203, The World Bank, Washington, D.C.

Feder, G., T. Ouchan and T. Raparla., 1986. Land Ownership Security and Access to Credit in Rural Thailand, Agricultural Research Unit Discussion Paper No. 153, The World Bank, Washington, D.C.

Food and Agricultural Organization (FAO) and Deutsche Gesellschaft fur Technische Zusammenarbeit (GTZ), 1998. Agricultural Finance Revisisted: Why?, Rome Italy.

Holt, S., 1990. The Role of Institutions in Poverty Reduction, Background Paper for World Development Report 1990, The World Bank, Washington, D.C.

Holt, S. L. and H. Ribe., 1991. Developing Financial Institutions for the Poor and Reducing Barriers to Access for Women, Discussion Paper No. 117, The World Bank, Washington, D.C.

Hossain, M. and R. Afsar., 1989. Credit for Women's Involvement in Economic Activities in Rural Bangladesh, B15 Research Report No. 105, Bangladesh Institute of Development Studies, Dhaka.

Hung, G. N. T., 2004. "Bank on Wheels", Finance and Development, $41(2): 41-43$.

Huppi, M. and G. Feder., 1990. "The role of groups and credit cooperatives in rural lending", The World Bank Research Observer, 5(2): 187-204.

International Fund for Agricultural Development (IFAD). 2000. IFAD Policy on Rural Finance, Rome Italy.

International Fund for Agricultural Development (IFAD). 2001. Rural Finance for the Poor: From Unsustainable Projects to Sustainable Institutions, Rome, Italy.

International Monetary Fund (IMF)., 2010. "Locked-in loans", Finance and Development, 47 (2): 2.

Johnny, M., 1995. Informal Credit for Integrated Rural Development in Sierra Leone, Homburg: Verlag Weltarchiv.

King, E. and R. Evenson., 1983. "Time allocation and home production in Philippine rural households", In Women and Poverty in the Third World. 
Klein, B., R. Meyer, A. Hannig, J. Burnett and M. Fiebig., 1999. Better Practices in Agricultural Lending, FAO/GTZ.

Laure, M., 1973. "Training for agricultural services". Paper presented at FAO Seminar on Agricultural Credit for Selected Countries in the Near East, FAO, Rome.

Littlefield, E. and R. Rosenberg. 2004. "Microfinance and the poor", Finance and Development, 41(2): 38-40.

Mann, C. K., M. S. Grindle and P. Shipton. (eds)., 1989. Solution: Framework and Cases for Small Enterprise Development Programmes, West Hartford, Conn.: Kumarian Press, Inc.

Markowski, P., 2001. "Microfinance innovations in the Gulf of Guinea region". In Food Security in a Changing Africa, S. A. Breth (ed.), Proceedings of the Workshop on Africa Food Security in a Changing Environment: Sharing Good Practices and Experiences, held in Kampala, Uganda, June 6-9.

Meyer, R. L. and C. Gonzalez-Vega., 1986. "Rural deposit mobilization in developing countries", Entwicklungund Laendlicher Raum, 20(1): 9-11.

Reichman, R., 1989. "Women's participation in two PVO credit programmes for microenterprises: Cases from the Dominican Republic and Peru". In Women's Ventures: Assistance to the Informal Sector in Latin America, M. Berger and M. Buvinic (eds.), West Hartford, Conn.: Kumarian Press, Inc.

Roberts, R. A. J., 1980. "Applied research and training in agricultural credit institutions". In Borrowers and Lenders, J. Howell (ed.), Overseas Development Institute (ODI), London.

Saito, K., H. Mekonnen and D. Spurling., 1994. Raising the Productivity of Women Farmers in Sub-
Saharan Africa, Discussion Paper No. 230, The World Bank, Washington, D.C.

Seibel, H. D., 2000. "Agricultural Development Banks: Close them or reform them? Finance and Development, : 45-48.

Stickley, T., 1976. The Agricultural Credit System in Tunisia: Some Observations and Recommendations, Department of Agricultural and Applied Economics, University of Minnesota, United States of America.

Stiglitz, J. E., 1990. "Peer monitoring and credit markets", The World Bank Economic Review, 4 (3): $351-366$.

United States Agency for International Development (USAID)., 1983. Project Paper, Bangladesh: Rural Finance Project, Dhaka.

Upton, M. 1973. Farm Management in Africa: The Principles of Production and Planning, Oxford University Press, London.

Von Pischke, J. D., 1989. Finance at the Frontier: Debt Capacity and the Role of Credit in Developing the Private Economy, The World Bank, Washington, D.C. Draft.

Von Pischke, J. D. and J. Rouse., 1983. "Selected successful experiences in agricultural credit and rural finance in Africa", Savings and Development, 1:21-44.

World Bank. 2008. Rural Finance in Nigeria: Integrating New Approaches, World Bank, Washington, D.C.

Yaron, J., 1994. What makes rural finance institutions successful?" The World Bank Research Observer, 9 (1): 49-70.

Yaron, J., 1995. Successful Rural Finance Institutions. Discussion Paper No. 150, The World Bank, Washington, D.C. 